Ethos: Jurnal Penelitian dan Pengabdian kepada Masyarakat, Vol 8, No.2, Juni 2020: 257-264

\title{
Upaya Pelestarian Permainan Tradisional melalui Kegiatan Kemah BaKti MASYARAKAT
}

\section{${ }^{1}$ Arif Widodo, ${ }^{2}$ Muhammad Tahir, ${ }^{3}$ Mohammad Archi Maulyda, ${ }^{4}$ Deni Sutisna, ${ }^{5}$ Muhammad Sobri, ${ }^{6}$ Muhammad Syazali, ${ }^{7}$ Radiusman}

\author{
1,2,3,4,5,6,7 Universitas Mataram, Mataram, Nusa Tenggara Barat, Indonesia \\ email: ${ }^{1}$ arifwidodo@unram.ac.id, ${ }^{2}$ sasakrengganis@unram.ac.id, ${ }^{3}$ archimaulyda@unram.ac.id, \\ ${ }^{4}$ denisutisna@unram.ac.id, ${ }^{5}$ muhammad.sobri@unram.ac.id, ${ }^{6}$ m.syazali@unram.ac.id, \\ ${ }^{7}$ radius_saragih88@unram.ac.id
}

\begin{abstract}
Traditional games have deep philosophical meaning in the history of the nation's struggle. Unfortunately, the advance of technology that presents a massive online game has displaced traditional games. Children and young people, notably, are no longer familiar with typical traditional games in their own regions. An effort to preserve traditional games in Batu Butir Hamlet of Kekait Village is done through community service activities. The problem solving method applied in this research is participatory observation through community service camps. The steps are situation analysis, socialization, and education to the public. Community service team members blend into the community during the service activities. Participants in this activity are school-age children and teenagers at Batu Butir Hamlet, Kekait Village, Gunung Sari-Lombok Barat. The activity involves 85 students who are members of the study program student association (HMPS). Efforts to preserve traditional games are carried out through socialization and competition activities in the community. The types of games contested are sack racing, tug of war, marbles racing, and long dragon games. It is hoped that these activities will encourage the community to put the online games away since they are proven to have a bad impact on health. Students involved in this activity are expected to be accustomed to living with and get closer to the community.

Keywords: Preservation, Traditional games, Community Service Camp/kemah bakti masyarakat (KBM)
\end{abstract}

\begin{abstract}
Abstrak. Permainan tradisional mengandung makna filosofis yang mendalam dalam sejarah perjuangan bangsa. Keberadaan game online secara masif telah menggusur keberadaan permainan tradisional. Berbagai kalangan termasuk anak-anak dan generasi muda sudah tidak lagi mengenal permainan tradisional di daerahnya. Kegiatan pengabdian ini bertujuan melestarikan permainan tradisional di masyarakat dusun Batu Butir Kekait. Metode pemecahan masalah dilakukan dengan observasi partisipasif melalui kemah bakti masyarakat. Adapun langkah-langkahnya adalah analisis situasi, sosialisasi dan pemberian edukasi kepada masyarakat. Anggota tim pengabdian membaur dengan masyarakat selama kegiatan pengabdian berlangsung. Peserta adalah anak-anak usia sekolah dan remaja kampung di Dusun Batu Butir Desa Kekait kec.Gunung Sari-Lombok Barat. Kegiatan melibatkan mahasiswa yang tergabung dalam himpunan mahasiswa program studi (HMPS) sebanyak 85 mahasiswa. Upaya pelestarian permainan tradisional dilakukan melalui sosialisasi dan kegiatan perlombaan di masyarakat. Jenis permainan yang dilombakan adalah balap karung, tarik tambang, balap kelereng, dan permainan ular naga panjang. Setelah kegiatan ini diharapkan masyarakat tidak lagi kecanduan dengan game online yang terbukti memiliki dampak buruk terhadap kesehatan. Dari segi mahasiswa yang terlibat dalam kegiatan ini diharapkan dapat terbiasa hidup membaur lebih dekat pada masyarakat.
\end{abstract}

Kata Kunci: pelestarian, permainan tradisional, kemah bakti masyarakat (KBM) 


\section{Pendahuluan}

Permainan tradisional sebagai wujud kearifan lokal bangsa Indonesia memiliki makna yang sangat mendalam. Makna yang terdapat dalam permainan tradisional tidak hanya sebagai visualisasi budaya sosial masyarakat tetapi juga ungkapan rasa cinta terhadap sesama dan lingkungan alam sekitar (Fad, 2014). Dari sini dapat dipahami bahwa pada permainan tradisional terdapat nilai-nilai karakter yang secara tersirat telah diajarkan oleh orang tua kepada anak cucunya. Penanaman karakter lebih tepat jika dilakukan sejak dini. Hal ini dikarenakan usia dini merupakan periode awal yang sangat penting sebagai dasar tumbuh kembang kehidupan manusia(Andriani, 2012).

$$
\text { Terdapat beberapa hasil }
$$

penelitian yang menyatakan tentang manfaat permainan tradisional, diantaranya adalah permainan tradisional dapat memberikan efek yang positif terhadap pengembangan keterampilan sosial anak (Kurniati, 2006). Hasil penelitian lain menunjukkan bahwa permainan tradisional ternyata dapat meningkatkan keterampilan siswa dalam menghadapi era globalisasi (Prastowo, 2018). Penelitian (Khasanah, Prasetyo, \& Rakhmawati, 2012) yang mengkaji tentang jenis permainan tradisional di TK Tunas Rimba I Semarang menyimpulkan bahwa permainan tradisional tersebut dapat digunakan sebagai sarana pengembangan psikomotor anak, kognitif, sosial emosional, dan keterampilan bahasa. (Khasanah et al., 2012) lebih lanjut menyatakan bahwa melalui permaian tradisional anak usia dini dapat dikenalkan nilai-nilai budaya lokal yang sarat dengan pendidikan karakter.

Nilai-nilai karakter dalam permainan tradisional diantaranya: kejujuran, sportivitas, kegigihan dan kegotong royongan. Manfaat lain dari permainan tradisional diantaranya melatih daya konsentrasi anak, sikap, pengetahuan, ketangkasan serta pengembangan moral, nilai-nilai agama, sosial, bahasa dan fungsi motorik (Andriani, 2012). Dunia anak adalah dunia bermain. Melalui permainan perkembangan fisik dan mental anak dapat terlatih. Permainan modern cenderung mengasah kecerdasan otak saja, sehingga aktivitas fisik berkurang. Agar anak-anak terlatih secara seimbang antara kekuatan otot dan otak adalah dengan melakukan permainan tradisional (Purnomo, Wiradimadja, \& Kurniawan, 2019). Menurut (Hasanah, 2016) permainan tradisional dapat memberikan kontribusi secara langsung terhadap beberapa aspek dalam perkembangan anak diantaranya: 1) pembentukan fisik yang sehat, bugar, tangguh, unggul dan berdaya saing; 2) pembentukan mental meliputi: sportivitas, toleran, disiplin dan demokratis; 3) Pembentukan moral menjadi lebih tanggap, peka, jujur dan tulus; 4) pembentukan kemampuan sosial, yaitu mampu bersaing, bekerjasama, berdisiplin, bersahabat, dan berkebangsaan. Hal ini serupa dengan pendapat (Purwaningsih, 2006) yang menyatakan bahwa nilai-nilai yang terkandung dalam permainan tradisional diantaranya adalah nilai kegembiraan, nilai kebebasan, rasa berteman, nilai demokrasi,nilai kepemimpinan, rasa tanggung jawab, nilai kebersaman, nilai kepatuhan, melatih kecakapan berpikir serta nilai kejujuran dan sportivitas.

Dewasa ini permainan tradisional telah tergusur dengan keberadaan game online. Anak-anak remaja semakin banyak yang kecanduan dengan permainan virtual. Permainan tradisional mulai ditinggalkan, karena dianggap kuno serta melelahkan Demikian halnya yang terjadi di Dusun Batu Butir Desa Kekait Kec.Gunung Sari Lombok Barat. Berdasarkan observasi awal dapat 
diketahui bahwa anak-anak dan remaja di daerah tersebut lebih menyukai permainan virtual salah satunya adalah game online. Permaian tradisional telah banyak ditinggalkan. (Fad, 2014) lebih lanjut mengatakan bahwa sungguhpun permainan tradisional telah diadposi ke dalam bentuk virtual efek positif yang dirasakan tetaplah berbeda. Permainan tradisional akan berdampak positif jika dilakukan sesuai dengan aslinya. Jika hal ini dibiarkan berlanjut maka efek negatif permainan online akan semakin parah, selain itu keberdaan permainan tradsional akan terancam punah.

Berdasarkan latar belakang di atas maka perlu diadakan kegiatan pengabdian masyarakat dalam rangka melestarikan permainan tradisional. Kegiatan ini berisi sebuah ajakan kepada masyarakat untuk kembali membudayakan permainan tradisional dalam kehidupan sehari-hari. Tahapan kegiatan pengabdian ini antara lain sosialisasi dan edukasi yang dikemas dalam sebuah kegiatan kemah bakti masyarakat. Kegiatan serupa telah dilakukan dengan judul Peningkatan partisipasi masyarakat di bidang pendidikan melalui kemah bakti dan dakwah mahasiswa di kota Padang (Jendriadi, 2018). Namun yang membedakan dalam kemah bakti tersebut hanya fokus dalam bidang pendidikan, sedangkan pengabdian yang akan dilakukan ini edukasi masyarakat melalui permainan tradisional.

\section{Metode}

Metode yang digunakan dalam pemecahan masalah di masyarakat adalah melalui kegiatan sosialisasi dan edukasi. Sebelum melakukan kegiatan inti terlebih dahulu dilakukan analisis situasi terkait dengan masalah yang dihadapi oleh masyarakat desa. Setelah dilakukan analisis situasi kemudian dirancang metode pemecahan masalah yang akan ditawarkan. Berdasarkan analisis situasi dapat diketahui bahwa anak-anak dan remaja jarang sekali melakukan permianan tradisional. Selain itu banyak diantara mereka yang kecanduan game online sehingga mengganggu kesehatan serta menurunkan prestasi belajarnya di sekolah. Oleh karena itu disusunlah sebuah kegiatan pengabdian masyarakat yang dirancang dalam sebuah kegiatan kemah bakti masyarakat. Cara ini dilakukan agar tim pengabdian dapat berbaur secara langsung dan berpartisipasi lebih aktif di dalam masyarakat.

Solusi yang ditawarkan dalam kegiatan pengabdian ini adalah gerakan untuk melestarikan permianan tradisional. Pada tahap pertama dilakukan sosialisasi kepada masyarakat terkait dengan manfaat dan makna di balik permainan tradisional. Pada tahap kedua adalah dengan pemberian edukasi terhadap masyarakat. Kegiatan edukasi dirancang dalam bentuk perlombaan agar terlihat menarik sehingga anakanak dan remaja mau ikut serta dalam kegiatan tersebut. Setelah kegiatan ini diharapkan anak-anak dan remaja di dusun Batu Butir desa Kekait tidak lagi kecanduan game online serta permainan tradisional yang kaya manfaat dan nilainilai edukasi dapat terus lestari.

\section{Hasil dan Pembahasan}

Kemah bakti masyarakat dengan tema "Totalitas Dalam Pengabdian Menggapai Sukses Masa Depan Melalui Himpunan" telah selesai dilakukan. Kegiatan tersebut dilaksanakan pada hari 
Minggu tanggal 9 sampai dengan Jumat 14 Februari 2020. Kemah bakti masyarakat terselenggara atas inisiasi Himpunan Mahasiswa Program Studi PGSD (HMPS) Universitas Mataram yang didampingi oleh tujuh dosen yang bertugas di Prodi PGSD Universitas Mataram. Jumlah mahasiswa yang tergabung dalam kegiatan tersebut sebanyak 85 mahasiswa. KBM tersebut terdiri dari beberapa rangkaian kegiatan salah satunya adalah upaya pelestarian permainan tradisional di masyarakat di Dusun Batu Butir Desa Kekait kec.Gunung Sari kab. Lombok Barat.

Upaya pelestarian permainan tradsional masyarakat di Dusun Batu Butir Desa Kekait kec.Gunung SariLombok Barat dilakukan dengan beberapa tahapan. Pada tahapan pertama dilakukan sosialisasi tentang manfaat permainan tradisional serta bahanya permainan game online (Permana \& Cendana, 2019). Pada tahap selanjutnya anak-anak dan remaja diberi pengetahuan tentang jenis-jenis permainan tradisional dan cara permainannya. Setelah diberi tahu aturan main selanjutnya diadakan perlombaan permainan tradisional baik secara individu maupun secara kelompok. Pada tahap ini kegiatan edukasi secara tidak langsung telah dilaksanakan. Tim pengabdian yang bertugas memandu jalannya acara tidak henti-hentinya memberikan orasi tentang manfaat permainan tradisional. Jenis permainan yang diperlombakan adalah balap karung, balap kelereng, permianan ular naga panjang dan tarik tambang. Berbagai macam jenis permainan di atas diperkenalkan kembali kepada masyarakat mengingat permainan tersebut memiliki makna filosofis dalam perspektif sejarah perjuangan bangsa. Makna lain yang terkandung dalam permainan di atas adalah nilai-nilai kebersamaan yang harus selalu dijunjung tinggi sebagai sarana pemersatu bangsa. Permainan tradsional mengandung makna perjuangan dan kebersamaan.

Pada hari pertama kemah bakti masyarakat diawali dengan gotong royong mendirikan tenda, mengingat kedatangan tim telah sore hari. Setelah pendirian tenda selesai dilakukan kunjungan ke rumah kepala dusun (Kadus) dalam rangka silaturahmi dan meminta izin melakukan kegiatan. Kunjungan kali ini menegaskan kembali tujuan pelaksanaan kegiatan yang telah disepakati bersama dengan Kadus beberapa waktu sebelum kegiatan dimulai.

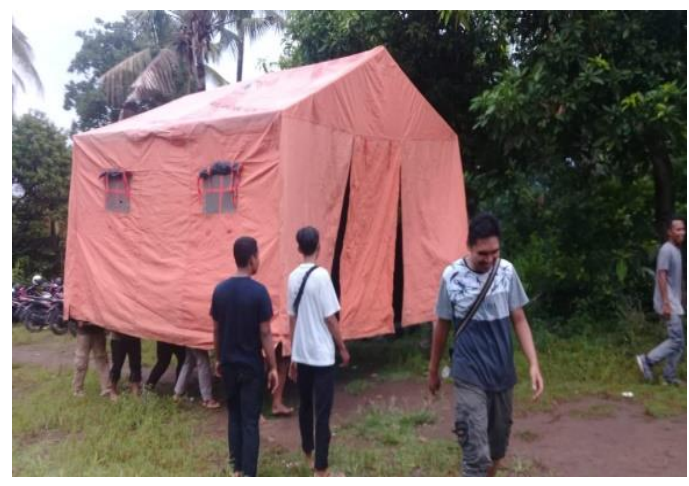

Gambar 1. Gotong royong pendirian tenda

Pada gambar di atas terlihat anggota tim pengabdian bersama mahasiswa gotong royong mendirikan tenda. Pada keesokan harinya bertepatan dengan hari senin dilakukan upacara bendera sekaligus upacara pembukaan kegiatan. Upacara pembukaan dilakukan di SDI "Amanah" Kekait. Sekolah ini dijadikan tempat pembukaan acara mengingat kegiatan kemah bakti masyarakat tidak hanya dilakukan di lingkungan masyarakat tetapi juga dilakukan di sekolahan. 


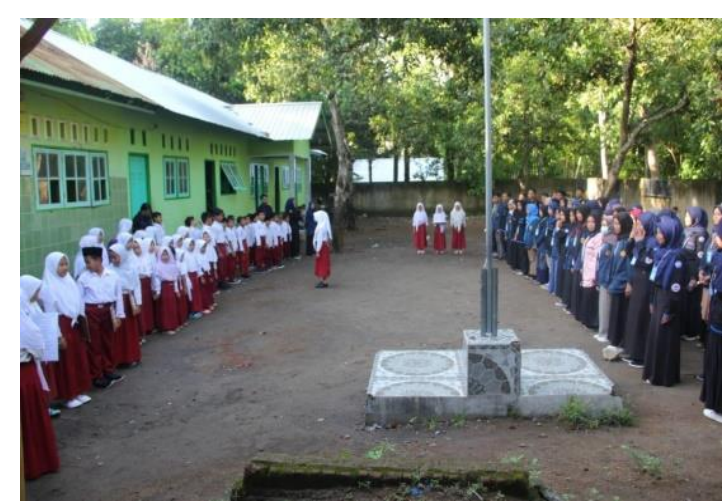

Gambar 2. Upacara Pembukaan kegiatan pengabdian

Gambar di atas terlihat anggota tim pengabdian sedang melakukan upacara pembukaan pengabdian. Setelah upacara pembukaan selesai masingmasing anggota tim pengabdian bekerja sesuai dengan tugas yang telah dibagi sebelumnya. Bagi anggota tim yang bertugas mengorganisir kegiatan di masyrakat segera bergegas mempersiapkan segala sesuatu yang diperlukan, salah satunya adalah untuk kegiatan lomba permainan tradisional. Pada sore hari masyarakat berkumpul di lapangan dusun Kekait yang letaknya tidak jauh dari permukiman warga. Dengan lokasi lapangan yang cukup luas satu persatu permianan tradisional dapat diperlombakan. Sebelum perlombaan dimulai anggota tim pengabdian melakukan simulasi terkait dengan aturan main permainan, mengingat tidak semua anak-anak dan remaja di dusun tersebut memahami aturan main masingmasing permainan.

Permainan tradisional yang pertama kali diperlombakan adalah balap kelereng. Antusiasme anak-anak dalam mengikuti lomba balap kelereng dapat terlihat dari gambar 3. Balap kelereng diperlombakan dengan alasan balap kelereng dapat mengajarkan ketangkasan, kejujuran, ketenangan dan konsentrasi. Permainan ini mengandung makna jika kita mempunyai tujuan yang baik maka fokus saja, jalan terus, jangan lagi menghiraukan godaan yang ada disekitar.

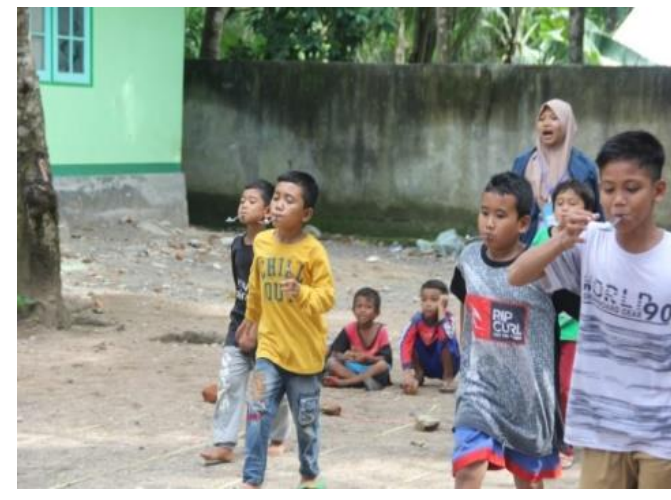

Gambar 3. Lomba balap kelereng

Permainan selanjutnya yang diperlombakan adalah balap karung. Permainan ini mengandung nilai historis yang tinggi. Karung mengingatkan generasi muda dengan pakaian yang dipakai orang tua dulu pada zaman penjajahan Jepang. Sejarah telah menulis bahwa penderitaan rakyat pada zaman penjajahan Jepang sangat berat baik dari segi sosial, politik dan ekonomi. Orang tua dulu pada zaman Jepang tidak mampu membeli kain sebagai pakaian, hingga akhirnya "karung Goni" yang dipakai sebagai pakaian sehari-hari. Untuk mengingatkan generasi muda akan penderitaan dan perjuangan orang tua terhadap penjajah Jepang maka

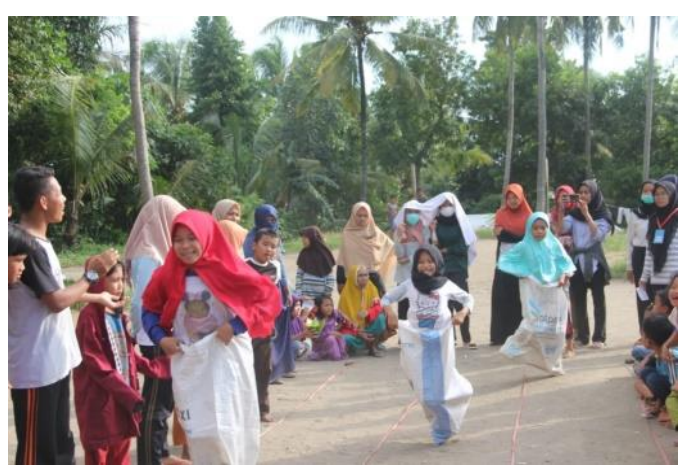

dibuatlah permainan balap karung tersebut.

\section{Gambar 4. Lomba balap karung}

Balap karung selain mengandung nilai historis dan perjuangan juga mengandung nilai-nilai yang dapat 
diaktualisasikan dalam kehidupan sehari-hari, seperti ketangkasan, konsentrasi dan ketangguhan. Melalui permainan tersebut dapat diambil makna bahwa kekuatan fisik harus diimbangi dengan keterampilan yang baik agar dapat mencapai tujuan yang diharapkan. Permainan selanjutnya yang diperlombakan adalah tarik tambang.

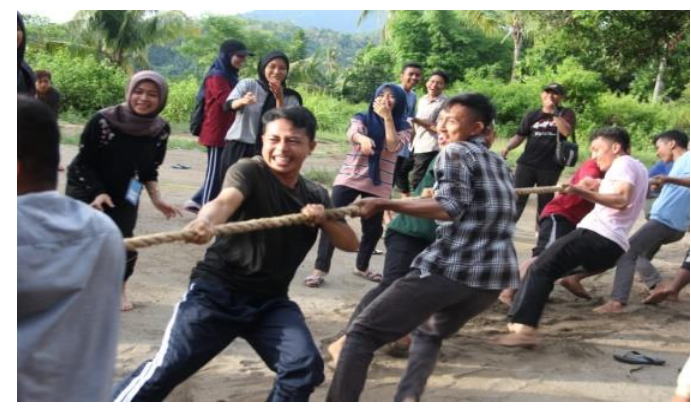

\section{Gambar 5. Lomba tarik tambang dewasa}

Gambar di atas memperlihatkan anggota tim pengabdian sedang berjuang untuk mengalahkan tim remaja dari dusun kekait. Walaupun telah berjuang dengan sekuat tenaga anggota tim pengabdian tidak mampu menandingi ketangguhan dari tim remaja dusun kekait. Keseruan lomba tarik tambang tidak hanya dari tim dewasa saja, tetapi juga berlaku untuk tim anak-anak. Keseruan tarik tambang tim anak-anak dapat terlihat pada gambar di bawah ini.

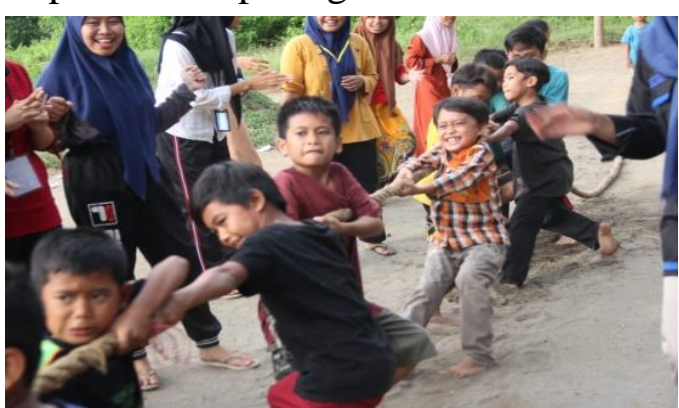

\section{Gambar 6. Lomba tarik tambang kategori anak-anak}

Berdasarkan gambar di atas dapat terlihat anak-anak mengikuti lomba tarik tambang dengan sangat serius. Anak-anak terlihat mengeluarkan seluruh tenaga yang dimiliki untuk mengalahkan tim lawan. Permainan tarik tambang mengandung makna kerjasama, dan persatuan dalam perjuangan. Selain itu tarik tambang juga mengandung nilai historis. Dari sisi historis tarik tambang mengandung makna menumbangkan kekuatan jahat. Dalam menumbangkan kekuatan jahat dibutuhkan kerjasama dan persatuan yang erat dari segenap masyarakat. Lomba tradisional terakhir yang diperlombakan adalah perminan ular naga panjang.

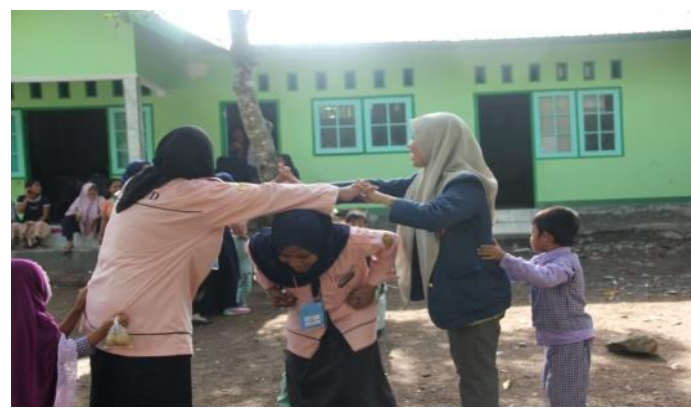

\section{Gambar 7. Permainan ular naga} panjang

Permainan ular naga panjang dilakukan secara berkelompok. Dalam permainan ular naga mengandung nilianilai edukasi yang tinggi diantaranya dapat mengembangkan kecerdasan, melatih kerjasama, dan melatih anak bersosialisasi. Berdasarkan gambar di atas dapat terlihat anak-anak sangat antusias dalam mengikuti permainan dengan bimbingan tim pengabdian. Anak-anak tidak terlihat canggung ketika harus bermain dengan orangorang yang baru saja di kenal. Dari sini dapat diambil kesimpulan bahwa permainan tradisional dapat efektif dalam mendidik anak-anak agar mudah bersosialisasi. Hal ini sesuai dengan pendapat (Kurniati, 2016) bahwa permainan tradisional dapat mengembangkan keterampilan sosial anak. 


\section{Kesimpulan dan Saran}

Berdasarkan kegiatan kemah bakti masyarakat (KBM) Himpunan Mahasiswa Program studi PGSD Universitas Mataram di Dusun Batu Butir Desa Kekait Kec.Gunung SariLombok Barat dengan tema "Totalitas Dalam Pengabdian Menggapai Sukses Masa Depan Melalui Himpunan" telah diperoleh beberapa kesimpulan diantaranya adalah masyarakat ternyata sangat antusias untuk melestarikan permainan tradisional sebagai warisan dari nenek moyang terdahulu. Masyrakat semakin sadar bahwa game online yang telah membuat kecanduan anak-anak muda memiliki dampak yang sangat buruk dari segi kesehatan maupun perkembangan psikologis anak-anak dan remaja.

Beberapa saran yang dapat diberikan setelah kegiatan pengabdian ini diantaranya adalah:

1. Bagi masyarakat yang memiliki anak usia remaja hendaknya selalu mengawasi anak-anaknya agar sering melakukan kegiatan yang membutuhkan aktivitas fisik seperti permianan tradisional agar tidak kecanduan dengan game online.

2. Bagi HMPS hendaknya kegiatan ini menjadi ajang untuk bersosialisasi dengan masyarakat, menghargai perbedaan dalam masyarakat yang mejemuk.

3. Bagi Program Studi PGSD hendaknya selalu konsisten untuk menyelenggarakan kegiatan pengabdian masyarakat seperti ini serta memperluas jangkauan pengabdian sehingga dapat dirasakan oleh masyarakat luas di provinsi NTB.

\section{DAFTAR PUSTAKA}

Andriani, T. (2012). Permainan Tradisional Dalam Membentuk Karakter Anak Usia Dini. Jurnal Sosial Budaya, 9(1), 121-136.

Fad, A. (2014). Kumpulan Permainan Anak Tradisional Indonesia. Jakarta: Cerdas Interaktif.

Hasanah, U. (2016). Pengembangan Kemampuan Fisik Motorik Melalui Permainan Tradisional Bagi Anak Usia Dini. Jurnal Pendidikan Anak, 5(1). https://doi.org/10.21831/jpa.v5i1.12 368

Jendriadi. (2018). Peningkatan Partisipasi Masyarakat Di Bidang Pendidikan Melalui Kemah Bakti Dan Dakwah Mahasiswa Di Kota Padang. MATAPPA: Jurnal Pengabdian Kepada Masyarakat, 1(1), 82-85.

Khasanah, I., Prasetyo, A., \& Rakhmawati, E. (2012). Permainan Tradisional Sebagai Media Stimulasi Aspek Perkembangan Anak Usia Dini. Paudia: Jurnal Penelitian Dalam Bidang Pendidikan Anak Usia Dini, 1(1). https://doi.org/10.26877/paudia.v1i1 .261

Kurniati, E. (2006). Program Bimbingan Untuk Mengembangkan Keterampilan Sosial Anak Melalui Permainan Tradisional. Pedagogia Jurnal Ilmu Pendidikan, 4, 97-114.

Permana, S. D. H., \& Cendana, M. (2019). Pemanfaatan Sosial Media Sebagai Strategi Promosi Bagi Sustainability Bisnis UMKM. Ethos: Jurnal Penelitian Dan Pengabdian Masyarakat, 7(2), 163-169.

Prastowo, A. (2018). Permainan Tradisional Jawa Sebagai Strategi Pembelajaran Berbasis Kearifan Lokal Untuk Menumbuhkan Keterampilan Global Di Mi/Sd. JMIE (Journal of Madrasah Ibtidaiyah Education), 2(1), 1. 
264 Arif Widodo, et al.

https://doi.org/10.32934/jmie.v2i1.5

5

Purnomo, A., Wiradimadja, A., \&

Kurniawan, B. (2019).

Pendampingan Komunitas Bhakti

Alam Sendang Biru Untuk

Pengembangan Informasi Wisata.

Ethos: Jurnal Penelitian Dan

Pengabdian Masyarakat, 7(1), 1-8.

Purwaningsih, E. (2006). Permainan

Tradisional Anak: Salah Satu

Khasanah Budaya yang Perlu

Dilestarikan. Jantra: Jurnal Sejarah

Dan Budaya, I(1), 40-46. 